\title{
The Youth, The Sciences Students, and Religious Radicalism
}

\author{
Yusar \\ Universitas Padjadjaran \\ yusar@unpad.ac.id
}

\begin{abstract}
This article is an endeavor to describe the tendency of religious radicalism amongst student of science at senior high schools and the students of several universities such as the faculty of medicine, pharmacy, and agriculture.. In many cases students or young people are the main target of the religious radicalism agents. The youth then receive the transmission of the religious radicalism and regenerate those values. In fact, the students of sciences, as individual with science education are more likely become member of religious radicalism group than other students such as humanities or social science. Why? This article portrays the causality of one's joined the religious radicalism group by the micro sociological approaches divided into two main factors such the individual states of minds of their world views and the student's relative deprivation.
\end{abstract}

\begin{abstract}
Abstrak
Artikel ini berupaya menggambarkan radikalisme agama di kalangan kaum muda yang tergolong sebagai siswa ilmu pengetahuan alam (IPA). Pada banyak kasus, golongan kaum muda merupakan sasaran utama para agen radikalisme agama. Kaum muda menerima nilai-nilai dan menjadi kader dari gerakan radikalime agama tersebut. Pada tataran empiris, para siswa rumpun IPA secara individu memiliki kecenderungan menjadi golongan radikal dibandingkan siswa-siswa yang tidak menempuh pendidikan rumpun IPA. Dengan pendekatan mikrososiologi, artikel ini memerikan 2 (dua) faktor penyebab para siswa rumpun IPA memiliki kecenderungan menjadi agen golongan radikal, yakni alam subyektif individu dan deprivasi relatif yang dialami oleh para siswa rumpun IPA.
\end{abstract}

Keywords Youth, Sciences, Students, Religious Radicalism 


\section{A. Introduction}

Religious radicalism has become problem in several region of the world. In the Indonesian history, even before the terrorist attacks of September $11^{\text {th }} 2001$, religious radicalism movement had a close relation with the independence and post-independence struggle ${ }^{1}$. Various religious radicalism movements were a part of the Indonesian movement against the colonialism. New religious radicalism movement might began in the $1980 \mathrm{~s}^{2}$ and crystalized in late 1990s parallel with the New Order Regime downfall. In the post New Order Regime, Indonesia embraced the democratization in which the religious radicalism having chance transmitting their movement widespread among the nation. The downfall of the New Order regime was the critical juncture accompanied with the intensification of religious conflict in Indonesia. ${ }^{3}$ In early 2000s, Indonesia faced many communally conflicts based on religion differences. That is the fact that religion has always stirred high emotions in Indonesia. As the high tension on religion, in Indonesian context, religious identity is more important than other identity such ethnicity, occupation, or other.

In the 2000s many researchers would agree that socio-economic inequality created mass frustrations. The communally conflicts reflected the socio-economic inequality in within the nation. There was a high sentiments form the lower class reacted against their frustration into communally conflict while religion was used as an instrument. In that case, the muslim were categorized as the lower socio-economics level. Politicizing the religious symbols has made religion function more as a means of social control ${ }^{4}$. Religion had decline to fostering the social cohesion for a whole country but for only specific interest group. It means that religion encompasses the issues of social justice, tolerance, inclusion and social integration. Another significance is the state power. When

\footnotetext{
1 Yusar, Pertemanan Sebaya Sebagai Arena Pendidikan Deradikaliasasi Agama, Walisongo, Vol. 23. No. 1, 2015.

${ }^{2}$ Martin van Bruinessen, Genealogies of Islamic Radicalism in Post-Suharto Indonesia, South East Asia Research, Vol. 10, No. 2, 2002, p. 117, http:///www. dspace.library.uu.nl/ bitstream/handle/1874/20378/bruinessen_02_genealogies_islamicradicalism.pdf?sequen ce $=1$, accessed August $3^{\text {th }} 2016$.

${ }^{3}$ Jacques Bertrand, Nationalism and Ethnic Conflict in Indonesia. (New York: Cambridge University Press), 2004, p. 102

${ }^{4}$ Norhaidi Hasan, Reformasi, Religious Diversity, and Islamic Radicalism after Soeharto, Journal of Indonesian Social Science and Humanities, Vol. 1, No.1. 2008, p. 37. http://www.kitlv-journals.nl/index.php/jissh/index. Accesed 3 February 2016
} 
religion used as an instrument concurent with the weakening of state power would reslut an increasing risk in distrust and conflict in the society ${ }^{5}$

In other hand, according to Bruinessen, the embryo of the religious radicalism movement was created by the young intellectuals in $1980 \mathrm{~s}^{6}$. Formed by the colege student of engineering and natural science, Bruinessen's finding then used as the indicators to describe the strong connection between the type of education and the tend joining the religious radicalism movement.

In recent years the religious radicalism movement groups became more demonstrative. Many of Indonesian youth joined the religious radicalism groups and most of them were middle class-students (junior high school, high school, and college students $)^{7}$. It may assumed that Bruinessen's finding showing the heuristic of ethnographic evidence in religious radicalism nowadays. Along with the Bruinessen's finding, Lembaga Kajian Islam dan Perdamaian (LaKIP) has shown that the 49\% of the students were agree with the radical action in the name of their religion. ${ }^{8}$ It signed that the religious radicalism created by the young intellectuals in 1980's cultivated and reap their movements nowadays. In recent years many intra-campus organization ruled by the member of the radicalist movement ${ }^{9}$. The tarbiyah group in many universities spreads their influence to the high school students. They were promoting their ideology and also searching to increase their ideological member. It also shown that the education institution such school or college were not impermeable to the radicalism movement.

While many action were generated to promote the tolerance, religious freedom, ${ }^{10}$ and multicultural education, the radicalist has shown

\footnotetext{
${ }^{5}$ Gary D. Bouma, The Challenge of Religious Revivalism and Religious Diversity to Social Cohesion in Secular Societies, in Religious Diversity and Civil Society A Comparative Perspectives, ed. Bryan S. Turner (London: Bardwell Press, 2008), p. 1325.

${ }^{6}$ Op.cit, 2002, p. 117

${ }^{7}$ Op.cit 2015, p. 188

8 Abu Rokhmad, Radikalisme Islam dan Upaya Deradikalisasi Paham Radikal, Walisongo, Vol 20, No. 1, Mei 2012, p. 81, http://eprints.walisongo.ac.id/1931/1/Abu Rokhmad-Radikalisme_Islam. pdf, accessed August $4^{\text {th }} 2016$.

${ }^{9}$ Rubaidi, Variasi Gerakan Islam di Indonesia, Analisis, Vol. XI, No. 1, 2011, p. 38-39. ${ }^{10}$ Ilham Prisgunanto, Campaign Socialization Religious Freedom To ToleranceReligion of Student, Al Ulum, Vol. 12, No. 2. 2014, p. 451. http://www.journal. iaingorontalo.ac.id/index.php/au/article/view/422. Accessed July $19^{\text {th }} 2016$
} 
their force ultimately after the election in $2014^{11}$. The conflict has changed, not only between the religions but also in one religion. Several observation in the social media demonstrate the conflicts were mainly forced by youth. They were categorized as a students, both in colleges or in high schools.

Of course, not all of the college students and the high school students were interested to the radicalist movements. The students perceived still has the strong nationality ${ }^{12}$ and only the minor were joined the religious radicalism movement. In previous observations, the sciences student were easier to recruit than the social sciences students as the previous research shown that many engineer joined the religious radicalism movement. The question has constructed according this phenomena, how the sciences students were easier to join the religious radicalism movement? To answer that questions, a microsociological approach was constructed to examine the main factor of the youth involve in radicalist groups. The microsociological approach tend to concern the bases of social action and interaction among individual members of society. The focus of this approach mostly on the subjectivity of the individual life-experiences and their world view. The individual experiences constructed their unique world view led their motive to show a specific social actions in masy circumstances. The excellence of this approach is the abitility to determine the causing factors which lead the individuals taking into a specific action.

The aim of this article is to describe the individual involvement amongst students of science at senior high school and students in several universities to the religious radicalism movement with the microsociological approach. This approach gives the alternative explanation about the religious radicalism movement and would bring a new comprehension of the individual state of mind beyond their world views and also enriching the relative deprivation concept, in context of religious radicalism movements. The shape-narrow thinking of the students of science were forced by their state of mind then the addiction of the characteristic of the discplines which they studied, both in high school and in their university. This research has quite different with the previous

\footnotetext{
${ }^{11}$ Yusar, Perlawanan Kaum Muda Terhadap Hegemoni Radikalisme Agama, Mamangan, Vol. 2, No.1, 2015, p. 75

12 Anis Fauzi, Nationalism Among Students: A Comparison Between Students of Islamic Junior High School and Students of Junior High School in Serang Municipality and Serang Regency, Al Ulum, Vol. 15, No. 2. 2015. P. 299-318. http://www.journal. iaingorontalo.ac.id/index.php/au/article/view/422. Accessed July $19^{\text {th }} 2016$
} 
research constructed by many scholars. Mostly the previous research were using the macrosociological approach to describe how the education systems influencing to a specific students who become radicals, such as engineers ${ }^{13}$, unspecific students ${ }^{14}$, and high school students ${ }^{15}$. This research was observing a high school students in Kota Bandung who studied in natural science and the student of several university in Kota Bandung and Jatinangor who studied the science such as students of The Medical Faculty, Science Faculty, The Agriculture Faculty, and Enginering Faculty. However, this research findings shown the similarity and confirmed the previous research which constructed by many scholars.

This research is the extension of what I was doing in 2014. In social science, it define as the longitudinal research. To continue the previos research, the qualitative methods was constructed to approach the religious radicalism beyond the youth. As the extension, this research may parallel with my previous research. In previous research I found that the religious deradicalism can be constructed in the peer groups. The next previous research, my findings shown the resistance of youth against the religious radicalism group hegemony in the artistic visual communication in the social media. Later the research of Diego Gambetta and Steffan Hertog inspired me to focus on the subject or youth as an actor in the religious radicalism movements.

Data gatehered from youth who categorized as a high school students and also the university students. This research has observe and examined the six groups from three high schools in Kota Bandung which categorized as the high-ranked school, the middle-ranked school, and the lower-ranked school. This research also observed the eight groups of the student of the science studies, such as medical, pharmacy, physics, agriculture, and engineering from several public universities and private universities in Kota Bandung. This research was doing from March to June 2015 then was terminated due the long holiday of the university and continued from November 2015 until April 2016. Data gather by the deep observation and unstructured interview keeping the natural setting of the students life. The

${ }^{13}$ Diego Gambetta and Steffen Hertog, Why are they so many Enginer among Islamic Radicals?, European Journal of Sociology, Vol. 50, No. 2. 2009, p. 201-230.

14 Zachary Abuza, Political Islam and Violence in Indonesia (New York: Routledge, 2007), p. 66-83

${ }^{15}$ Ahmad Fuad Fanani, Fenomena Radikalisme di Kalangan Kaum Muda, Maarif, Vol. III, No.1. 2013, p. 6. 
total informants who included in this research was fifthy four informants. The multiply microsociological methods such the phenomenology, ethnometodology, and the framing methods were constructed to gain the comprehension of sciences student as individual to join the religious radicalism group. Several observation, text analyses, and framing on the subjects were useful to construct the theoretical conclusion. This article provides a new approach in term causality of individual decision to join the religious radicalism.

\section{B. Previous Research}

Many researchers were agreed that the radicalization is an amorphous concept. To avoid the misinterpretation, radicalism is a behavior or attitutude to express one's religousity. This concept has a meaning that radicalism is different with the terrorism. In other hand, the radicalization become a "one step before" act of terrors. ${ }^{16}$ In recent years, the radical movements was absorbed by the youth in various education institutions and confirmed that the radicalims values embedded within the youth. In this institution, the youth can be define as the students who in process of their searching for identity and socially has a wide range of their linkage among the youth. Youth also perceived as the otonomous groups who has a big differences in the structure of society-life. By the radical groups, youth considered as the strategic target for the profileration of the radicalism value.

Youth religious radicalim in Indonesi post-New Order could perceived as the response the identity crises within youth both in personal life and collective life of the youth itself. The youth also have a high tendency to involve in the radical movement rather than the adults ${ }^{17}$. It was signified that youth were became the agents of the radicalism movement, specially youth who has occupations as a stundents ${ }^{18}$. The youth was experiencing the identity crises in their life-cycle in the term of the cognitive opening, a microsociological process juxtaposed them

\footnotetext{
${ }^{16}$ Ibid, p. 4

17 Muhammad Najib Azca, Yang Muda Yang Radikal: Refleksi Sosiologis Terhadap Fenomena Radikalisme Kaum Muda Muslim di Indonesia Pasca Orde Baru, Maarif, Vol. III, No. 1. 2013, p. 19-20. http:maarifinstitute.org/images /../vol\%20viii\%20no\%201\%20juli\%20201. pdf. accessed 4 ${ }^{\text {th }}$ August 2016.

${ }_{18}$ Muhammad Iqbal Ahnaf, Struktur Politik dan Deradikalisasi Pendidikan Agama Bagi Anak Muda di Indonesia, Jurnal Pendidikan Islam, Vol. II. No. 1, 2013, p. 154. http:// www.jurnaljpi.com/index.php/JPI/article/view/24/24. Accessed 4th August 2016
} 
accepting the new ideas. They were learning various knowledge in the cognitive opening phase and found what was difference with their world view, such as inequality life, obsolote values, or other problems in their society. As the consquences, the other path is the moral shock which also experienced by the youth accompanied with their cognitive opening. The moral shock was cristalized when the youth saw various phenomena which raise their anger dan despairing them which further encourages the youth to engage in political or radical action. Futhermore, the moral shock raised the moral emotions, a solidarity process with a special groups ${ }^{19}$. The cognitive opening and the moral shock was the main factors for the youth to join the radical movements.

Youth was perceived as a suspectible segment against the radical movements which ongoing around them. In the 2009, Lembaga Kajian Islam dan Sosial (LkiS) found the high level intolerance among the students in the 20 high schools in Yogyakarta. The results shown that $69,9 \%$ students has a low level tolerance for those with religous differences ${ }^{20}$. The result indicates that the religious orientation among the youth tend to receptive to the intolerance and radicalism. In the future, it is not possible to make the youth as a significant social and political force which will change the Indonesian political scenes become more open to the radicalism political aspiration ${ }^{21}$.

The recent studies was shown six charateristics of the youth as actors of the religious radicalism: 1) intolerance; 2) takfiri; 3) the rigid adherence to the leader; 4) ruling the students campus units; 5) support the act of violences based on religion; 6) against the state government ${ }^{22}$. The radical student and university-based organizations that organize antiWestern protests and whose members may sympathize with more radical causes. They were form an opposition group against the government which considered as a secular agents and deviated from religious rules ${ }^{23}$.

The students who joined into the religious radicalism movement may categorized by the type of education. The students of social science are

\footnotetext{
${ }^{19}$ Op.cit., 2013, p. 29-30.

${ }^{20}$ Op.cit., 2013, p. 154.

${ }^{21}$ Ibid, 2013, p. 158

${ }^{22}$ Yusar, Perlawanan Kaum Muda Terhadap Hegemoni Radikalisme Agama, Mamangan, Vol. 2, No.1, 2015, p. 76

${ }^{23}$ Zachary Abuza, Political Islam and Violence in Indonesia (New York: Routledge, 2007), p. 66.
} 
less interested to the religious radicalism movement than the engineer. ${ }^{24}$. This importance findings lead the classification of the students who joined the religious radicalism movement. Gambetta and Hertog found that many engineers were joined the Islamic radicalism from several surveys and shown that the 78 out of 178 individuals $(43,3 \%)$ has studied the engineering in many universities and $56,7 \%$ were studied medicine and (natural) science. $69 \%$ of them are the higher education in engineering. Conducted with the violent attack based on religion, 13 out of $33(59,1 \%)$ were engineers. Engineers who conduct with non violent groups are 59 out of $147(44,1 \%)$ and the engineers who conduct with violent group are 78 out of $101(77,2 \%)^{25}$. Gambetta and Hertog was indicates the other educations (OEDs) such the medical, pharmacologist, and basic science; neglected the students of social science, philosophy, and humanities whose less interested to join the religious movement and tend to the socialist lefwings movements.

\section{Findings and Discussion}

The precious datas form Gambetta and Hertog leads this research to explore the student of sciences. A microsociological analyses constructed to explore on the state of mind on the students of sciences. Perceived by the society, the science such as medical, pharmacology, mathematics, physics science, chemical science, and also agriculture sciences are 'the elite education" rather than social and humanities. The perception was constructing the assumption that the science students are having an academic superiority than the social and humanities students.

Continued from previous research, this research firstly identify the religious group in many campuses both in the high schools and the universities. Both of them have a common similarity, a specific group with an exclusivity and hardly to accept individuals without their mechanism of acceptance. This identification then lead to identify the members of these groups. Most of them dominated by the students of natural science or science studies. The small-scale unsignificants number of the social science students were ignored to maintain the research focus.

\footnotetext{
${ }^{24}$ Diego Gambetta and Steffen Hertog, Why are they so many Enginer among Islamic Radicals?, European Journal of Sociology, Vol. 50, No. 2. 2009, p. 201-230.

${ }^{25}$ Ibid., 2009, p. 204-209.
} 
Table. 1

The Type of School, Status, Number, Number of Group, and Dominant Subject Studies of Group Members

\begin{tabular}{|l|l|c|c|l|}
\hline School & Status & Number & $\begin{array}{c}\text { Number } \\
\text { of } \\
\text { Group }\end{array}$ & $\begin{array}{c}\text { Dominant Subject } \\
\text { Studies of Group } \\
\text { Member }\end{array}$ \\
\hline $\begin{array}{l}\text { High } \\
\text { School }\end{array}$ & Public & 2 & 4 & Natural Science \\
\cline { 2 - 5 } & Private & 1 & 2 & Natural Science \\
\hline University & Public & 4 & 6 & $\begin{array}{l}\text { Medical } \\
\text { Pharmacology } \\
\text { Science } \\
\text { Engineering } \\
\text { Agriculture }\end{array}$ \\
\cline { 2 - 5 } & Private & 2 & 2 & $\begin{array}{l}\text { Applied Science } \\
\text { Information and Technology }\end{array}$ \\
\hline
\end{tabular}

The subject on this research were aged between 15 to 22 years. Each of group were dominated by male. We can not simply signify that the male are dominating the science students in the high schools nor in the university.

What exactly about science students mindset or cognitive dispotition could match for the religious radicalism movement? Constructed to the Gambetta's dan Hertog's; the fact shown that the sciences educations more students joined the religious radicalism activity rather than the social sciences and humanities students. In addiction, concerning on gender distribution which dominated by male, we may define that the male would more demonstrate their action rather than female, in societal context. With the deep observation on the subjects and deepen by unstructured interviews to gain the datas, there are two mains factors that drives the sciences students to join the religious radicalism movements.

\section{1) State of Mind of The Science Students}

In this research, the subject dominated by a single individual who have a narrow thinking. They are mostly choose to study the natural science rather than the social science inaccordance with their individual character. Most of them categorized as a person who dislikes an ambiguity, sharpness, and have an ambitions to answer question directly. There were an exception in the high school students who in the class of natural science then enrolled to the social studies or art and humanities on the university 
such anthropology, sociology, communication studies, or linguistics and cultural studies.

In many universities, sciences such medical, pure science or applied science are a subject in which individuals dislike for an ambiguity answer. Science often claim that there is single way to solve the problems through logical dan technical approaches and it embed to the state of mind of the students. The sciences students were attracted to the single clear-cut anser with the cognitive closure opposed to more ended discourse.

Science as the subject offered a rigid procedures. It creates the students a sharp minds with loyal acceptance to the authority. There is no objection but the authority decide a single way to do as the implementation of science procedure. A network of radicalism recruiters is circulating on campuses targeting people who has a sharp mind, loyal, and seeking the single answered person who dislike the ambiguity, close minded, and have an orientation just to solve the problem rather constructing a discourse. The recruiter avoids person who open minded with the ambiguity, seeking the alternatives of answers, and like to develop a discourse.

The science faculty educates their students to become perseverant, patient, and steadfast. It connected to the jihadist memoirs aimed at recruiting members with a firm adherence to the principles and likely to be perseverant, patient, and steadfast. It also has conduct to the evidence that the radical movement tend to recruit the science students as Abuza found the Jemaah Islamiyyah has actively recruited in leading technical institutes, including the University of Technology Malaysia, Universitas Negeri Semarang, and Bandung Institute of Technology ${ }^{26}$.

From the students view, enrolling for a science student in higher education indicates a strong sign, ambitious, and excellent talent. The students -the high schools and the university student- in Kota Bandung and Jatinangor has show that they have a strong ambition and dislike an ambiguity. They tend to answer any question directly in short sentence, single truth amount. As perceived by society, the science students carries more than a mere smart thinking and technical expertise but also gain the high social status among the student and wider society ${ }^{27}$. In Indonesia the New Order regime entertained a technocratic rhetoric of development and

\footnotetext{
${ }^{26}$ Zachary Abuza, Education and Radicalization: Jemaah Islamiyah Recruitment in South East Asia, in The Making of a Terrorist. Recruitment, Training and Root Cause, ed. James J.F. Forest (London: Praeger, 2006 .), p. 78

${ }^{27}$ Op.cit., 2009, p. 223.
} 
actively encouraged the growth of sciences and technical faculties and the mass enrolment of students. It leads the children to enroll the natural science in high schools $\mathrm{f}$ and having a big hope to continue their study enrolling for a sciences studies or technical faculty.

According to Muhammad Najib Azca, the students who categorized as youth experienced the cognitive opening ${ }^{28}$. The students as the subject who observsed in this research categorized as the person who have sharp mind and dislike to an ambiguity, the sciences students are receive a new knowledge about religiousity which they don't know before. The process of the cognitive opening then leads the students to accept a single doctrines of the "truth". From the unstructured interview about the existence of the multi religion in their society, the students addresed the answer as they were unknowing the existence of people who has different faith. Mostly found in students of physics and engineer. Later they were stated that one who have different religion is their enemy. They believe that other religions are always threaten against their religion, And so, they will overcome the threatment with their efforts. There is no alternative question to critize the doctrine as the individual type of single clear-cut answer. The students state of mind then opening to the acceptance of the radical doctrines and starting to receive the "truth" as they totally obey the recruit as the authority and ready to run the procedures of recruitment. In the recruitment process, they were shared their experiences about their world views. The sciences students with the specific individual characters found the similarity of their life-experiences and form the strong cohesion between them define by "us" terminology.

Without critizing the new knowledge, the students were experience to the next phase - moral shock ${ }^{29}$. They viewed the world in a single perspective that he/she in a bad condition and also the society around them. The students have a strong feeling that their religion is on under the threatment form the enemies, such secularism, pluralism, and also humanism. They do believe on the conspirative assumption that the world ruled by a group of global elites who threaten their religious life. Based on the recruiter's doctrines, the students then perceived that the society in

28 Muhammad Najib Azca, Yang Muda Yang Radikal: Refleksi Sosiologis Terhadap Fenomena Radikalisme Kaum Muda Muslim di Indonesia Pasca Orde Baru, Maarif, Vol. III, No. 1. 2013, p. 19-20. http:maarifinstitute.org/images/../vol\%20 viii\%20no\%201\%20juli\%20201.pdf. accessed $4^{\text {th }}$ August 2016.

${ }^{29}$ Ibid., 2013, p. 19-20. 
which they live is controlled by the kuffar systems. Conducted with the single persepective person, they viewed themself as the agents of the truth; one's who is not agreed or differs from he/she labelled as the agents of kuffar. The student become ignore the differences between them and the society around. They began withdrawing themselves from friendship or society and formed an exclusive group based on common world view. The exclusive group not only withdraw from wider society but also signified with a strong chauvinisticsm.

Along with Muhammad Najib Azca, this research also found that the students was experienced the moral emotion ${ }^{30}$. From the unstructured interviews, mostly the knew that their religioun is under threatment from its enemy since they were in the high school. This information were told by their seniors or their mentors in the religious activities in their schools. The solidarity formed in the exclusive-chauvinistics group of the student. As the persons with strong ambition and excellent talents, the compact solidarity between the students cristalized onto question how they can solve the problems - the kuffar systems. Their sharp mind single clear-cut answer to solve the problem often tend to opposite everything that differs with their truth by mono logical-technical arguments and not to open the space for discussion nor critical discourse. That is, the sciences students who joined the religious radical movement are more often charaterized with their militancy and totally obeying their leader.

As Diego Gambetta and Steffan Hertog findings about the engineers among the radical muslim, the students state of mind categorized as straight single clear-cut answer has deep meaning and reflect the coherence of the whole, the rationality of one ${ }^{31}$ with the single truth (God's). Their sentence in respond on the unstructured interviews about the probability and relativity of the truth and its uncertainty has shown the clarity that they have single answer as their truth. This phenomena lead them close their perspectives from reality of faith which exist in their social life. This is the significant finding on this research which may addressed to their exclusivity and intolerance to the others. Deep in the students realm of unconsciousness, the single clear-cut answer to solve the problem are highly connected with the belief that God is the answer. In their realm subsconciuos, they were acting as a group who gave the salvation in the

\footnotetext{
${ }^{30}$ Ibid., 2013, p. 19-20.

31 Op.cit.,. 2009, p. 221.
} 
name of God, liberating people from the kuffar systems. They believed that whoever opposite against them must be punished in the name of God.

\section{2) The Relative Deprivation On Youth}

Many scholars were provide us the relative deprivation theory and it useful to explain the radicalism recently. The limitation of this concept commonly in the socio-economics scences which may vary form each regions. In this articles, found that socio-economics was not the main problems but the sociopolitical scenes conduct with the youth as the students on sciences. As the previous chapter has been explain the state of mind of the student who joined the religious radicalism, in this chapter explained the socio-political that driven the students more radical.

The science students familiar with strict procedures for getting an answer to solve the problem. As the elite degree, the students thought that they should taking an action to solve the problems faced by the community. In fact, a diverse social life is different from the doctrine they receive. Therefore as individuals who have a strong ambition, above average intelligence, and has the logical-technical skills, making them even more must be done to change the situation. In this situation, the students often feel frustated facing the reality in which differs with their perception.

Various socio-political are stressing the students to become more radical stimulated by the idea of Indonesia as a state implenting the secular law. The students perceived that a nation state which muslim as a majority population should implementing sharia law. Although it raised the controversy not just among the muslim and the non muslims, but also between the muslims. They argued that in sharia, the minority will gain protection from the muslim as majority. From this issue, the students endeavor to force the implementation of sharia law. In general, the students are concerned with increasing moral problems of the country, which, they believe can only be solved by implementing sharia more comprehensively and assertively, not only in the conventional areas, such as marriage and worship within the Muslim community, but also in the wider public sphere of politics, the economy, public services, the media, civil law and education ${ }^{32}$. In fact, the state does not implementing sharia

\footnotetext{
${ }^{32}$ Yahya Wijaya, The Economic Ethics of Christian and Islamic Fundamentalism, in Overcoming Fundamentalism: Ethical Responses from Five Continents, ed. Heidi Hadsell and Christoph Stückelberger (Geneva: Globalethics.net, 2009), p. 131-150.
} 
law altough the muslim is the majority. It because the argument that Indonesia is not a muslim state and uphold the bhinneka tunggal ika as the motto of the nations.

The Indonesian diversity is also the condition that regarded erroneous. Many of adat were perceived as the contrary to the religious values or define as bida. Students who joined the radical religious movement demanding that leave the adat and replace them with religious life according to their religious values. After the fall of the New Order Regime, Indonesia politically faces the new challenge called democratization and implementing decentralization. This era points out that the local cultures have a new chance to raise their form as one of many cultures which lived in the people of the Republic Indonesia. ${ }^{33}$ These adat revivalism bring to the controversy between the radicalist and the adats. In other hands, various of adats were influenced by traditional Islamic values which define as Islam Nusantara.

The local traditional Islamic values dominated the muslim life in Indonesia. This condition. requires students who are members of the radical religious movements sued the Islam Nusantara sued and accused as heretics. As a reaction of the radicalist, the majority put the stigma against the radicals such as intolerance, the middle east cultural imposition, the takfiri, or the khawarij. This stigma escalate the tension between the radicalist and the traditional muslim.

In Indonesian political scene, the presidential election 2014 was brought the conflict escalation between the radicalist and the nationalism. The youth who joined the religious radicalism endorsing a presidential candidate who supported by Islamic parties. From the socal media on the internet, the youth radicals receive many wrong information or black campaign issue such ethnicity or religion to another presidential candidate. The radicalist doing the propaganda without considering the truth of those informations. It because the youth radicals have a loyality to their leader. The science students were also involve in that black campaign; the typical of the single clear-cut answer of them has made less consideration nor check and recheck (tabayyun) to the information in which they receive. Their action has replied by other youth who are not

\footnotetext{
${ }^{33}$ Yusar Muljadji, The Folk Underground Music as Culture Revivalism: Mixing The Sundanese Traditional Musical Instruments and Underground Music as the Struggle for Culture Souvereignty, in Keep It Simple Make It Fast Vol. II, eds Paula Guera and Tania Moreira (Porto: Universidade do Porto, 2016), p. 16.
} 
joined the religious radicalism movement by visual communication of the parody and satire against the youth who joined the religious radical movements. Along with Yusar Muljadji's finding, in the social media, there were a war between the youth by constructing a visual communication define as meme. ${ }^{34}$ The fact that presidential election in 2014 deliver Joko Widodo to the President of Republic Indonesia has made the youth, including the sciences student become more radical and increasing the intensity against the government with many kind strategies such deceptions or spreading false information. In the social media, the deception in memes can be perceive as an action toward the relative deprivation feeling which are sensed by youth who join the religious radicalism movements. The decepetion is their weapon to propagate their ideology to the mass.

These condition at certain level was made the frustrated condition in the youth radicals. The tension from their external conditions has been generating the youth including the sciences students who joined the religious radical movement became aggresively against the society beyond them and having a reply from their opposition such the nationalist or general students. In many campuses, the students who joined the religious radicalism were alienated by the other students. It gives the difficulties for the students who joined the religious radical movements to spread their influence or transmitting their radicalism values. Also, many campuses has develop a regulation to hamper their movements, the spaces of their movement was restricted by the campus regulations.

In context of the sciences students, the socio-economic factors was ignored due the wealth status of the students. The socio-economic factors might a main factor leads the relative deprivation to the non student groups. I also agree that the socio-economics is a main factor to push one's joined the religious radicalism movement. In this research, the evidence shown that the student were coming from the middle class - wealthy family.

Enrolling to the sciences studies signify a strong ambition. Conducted with the reality, it may appears that individuals with strong ambitions having frustrated by condition would make them more powerful to take an action. When the ambition and frustration collide, the students were not just frustrated on an individual level, but felt unable to discharge a collective responsibility. They endeavor to reinforce themselves to be

${ }^{34}$ Op.cit, 2015, p. 76 
able make a change in their society. This experience is a very plausible factor that they contributed to their radicalization ${ }^{35}$. That was a typical of narrow thinking which common in youth, who studied the sciences such medical or other sciences.

\section{Conclusion}

The linear way persepective lead them having the lesser critical thinking, controlled by their state of minds and strengthened by the strict procedures of the science. Therefore, the tension of the structural condition also challengingthem to become more radicals. The most plausible explanation of the sciences students joined with the religious radicalism lies in the joint effect of two causes, the state of mind and the relative deprivation. The state of minds of the students lead them to joining the religious radicalism movement individually. The structural tension define as the external conditions is forcing the radical group to generate their movement against the wider society. The combination of these two factors can not be ignored for the mutual benefit for our society.

It might important that the civic education is further enhanced in the sciences curriculum. With the additional of the multicultural awareness it is one step that can be taken to prevent the youth joining the radical religious movements which could threaten the unity of the nation and also be able to appreciate the relativity of cultures that exist around them as an effort to inculcate the tolerance of the differences.

\section{REFERENCES}

Abu Rokhmad, Radikalisme Islam dan Upaya Deradikalisasi Paham Radikal, Walisongo, Vol 20. No. 1. 2012, p. 81, http://eprints.walisongo.ac.id/ 1931/ 1/Abu_RokhmadRadikalisme_Islam.pdf. Accessed August $4^{\text {th }} 2016$.

Ahmad Fuad Fanani, 2013, Fenomena Radikalisme di Kalangan Kaum Muda, Maarif, Vol. III. No. 1. 2013, p. 4. http:maarifinstitute.org/images/../vol\%20 viii\%20no\%201\%20juli\%20201.pdf. accessed $4^{\text {th }}$ August 2016.

${ }^{35}$ Op.cit., 2009, p. 224. 
Anis Fauzi, Nationalism Among Students: A Comparison Between Students of Islamic Junior High School and Students of Junior High School in Serang Municipality and Serang Regency, Al Ulum, Vol. 15. No. 2. 2015, p. 299 -318. http://www.journal. iaingorontalo.ac.id/index.php/au/article/view/422. Accessed July $19^{\text {th }} 2016$

Diego Gambetta and Steffen Hertog, Why are they so many Enginer among Islamic Radicals?, European Journal of Sociology, Vol. 50. No.2. 2009, p. 201-230.

Gary D. Bouma, The Challenge of Religious Revivalism and Religious Diversity to Social Cohesion in Secular Societies, in Religious Diversity and Civil Society A Comparative Perspectives, ed. Bryan S. Turner (London: Bardwell Press, 2008), 13-25.

Ilham Prisgunanto, Campaign Socialization Religious Freedom To Tolerance Religion of Student, Al Ulum, Vol. 12. No. 2. 2014, p. 451.

http://www.journal. iaingorontalo.ac.id/index.php/au/article/view/422. Accessed July $19^{\text {th }} 2016$.

Jacques Bertrand, Nationalism and Ethnic Conflict in Indonesia. (New York: Cambridge University Press, 2004).

Martin van Bruineesen, Genealogies of Islamic Radicalism in PostSuharto Indonesia, South East Asia Research, Vol. 10. No. 2. 2013, p. 117, http:///www. dspace.library.uu.nl/ bitstream/handle/1874/20378/bruinessen _02_genealogies_islamicradicalism.pdf?sequence $=1$. Accesed $\overline{\text { August }} 3^{\text {th }} 2016$.

Muhammad Iqbal Ahnaf, Struktur Politik dan Deradikalisasi Pendidikan Agama Bagi Anak Muda di Indonesia, Jurnal Pendidikan Islam, Vol. II. No. 1. 2013, p. 154. http://www.jurnaljpi.com /index.php/JPI/article/view/24/24. Accessed 4th August 2016.

Muhammad Najib Azka, 2013, Yang Muda Yang Radikal: Refleksi Sosiologis Terhadap Fenomena Radikalisme Kaum Muda Muslim di Indonesia Pasca Orde Baru, Maarif, Vol. III. No. 1. 2013 p. 19$20 . \quad$ http: maarif 
institute.org/images/../vol\%20viii\%20no\%201\%20juli\%20201.pd f. Accessed 4th August 2016.

Norhaidi Hasan, Reformasi, Religious Diversity, and Islamic Radicalism after Soeharto, Journal of Indonesian Social Science and Humanities, Vol. 1. No.1. 2008, p. 37. http://www.kitlvjournals.nl/index.php/jissh/index. Accesed 3 February 2016.

Rubaidi, Variasi Gerakan Islam di Indonesia, Analisis, Vol. XI. No. 1. 2011, p. 3839.

Yahya Wijaya, The Economic Ethics of Christian and Islamic Fundamentalism, in Overcoming Fundamentalism: Ethical Responses from Five Continents, ed. Heidi Hadsell and Christoph Stückelberger (Geneva: Globalethics.net, 2009).

Yusar Muljadji, The Folk Underground Music as Culture Revivalism: Mixing The Sundanese Traditional Musical Instruments and Underground Music as the Struggle for Culture Souvereignty, in Keep It Simple Make It Fast Vol. II, eds Paula Guera and Tania Moreira (Porto: Universidade do Porto, 2016), p. 15-22.

Yusar, Perlawanan Kaum Muda Terhadap Hegemoni Radikalisme Agama, Mamangan, Vol. 2, No.1. 2015, p. 73-88

Yusar, Pertemanan Sebaya Sebagai Arena Pendidikan Deradikaliasasi Agama, Walisongo, Volume 23, No. 1. 2015, p. 177-196

Zachary Abuza, Political Islam and Violence in Indonesia. (New York: Routledge, 2007).

Zachary Abuza, Education and Radicalization: Jemaah Islamiyah Recruitment in South East Asia, in The Making of a Terrorist. Recruitment, Training and Root Cause, ed. James J.F. Forest (London: Praeger, 2006), p. 66-83. 